\title{
The Close-Up Eye Asymmetry Visual Metaphor COMMUNICATES THE ABJECT: EVIDENCE FROM BATMAN AND SUPERMAN COMICS
}

\author{
Igor Juricevic \\ Indiana University South Bend
}

\begin{abstract}
A distinctive theme of Gothic narratives is the abject. A character that is abject threatens to disrupt boundaries, both personal and societal. As such, the abject character must be rejected or destroyed by society. In this study, I propose that the visual metaphor of Close-Up Eye Asymmetry (CUE-A) communicates the concept of the abject in Gothic narratives. I then investigate this proposal by comparing how often CUE-A is used when depicting Batman compared to Superman in comic books. Overall, I provide evidence that: (1) Batman is more Gothic than Superman, (2) Batman is more abject than Superman, and (3) Batman is depicted with CUE-A more often than Superman. Taken together, this shows that CUE-A co-occurs with the concept of the abject in Gothic narratives, supporting the idea that the CUE-A visual metaphor does, in fact, communicate the abject in Gothic narratives.
\end{abstract}

Keywords: Gothic, visual metaphor, abjection, Batman, Superman

A distinctive theme of Gothic narratives is the idea of the abject character. During the process of socialization, a person is taught what is and what is not socially acceptable. To be accepted into society, a person undergoes a process that casts off what society deems unclean, disorderly, repulsive, or antisocial. "This process is termed abjection, and all the putatively improper stuff which the subject aims at casting off constitutes the abject" (Cavallaro 199).

There are numerous ways to communicate that a character is abject in a Gothic narrative. For instance, a character could be both dead and alive, as many of the classic Gothic monsters are, such as vampires, zombies, and mummies (Caroll 32). In this study, I will propose another way to communicate that a character is abject: the visual metaphor of Close-Up Eye 
Asymmetry (CUE-A). CUE-A consists of the combination of depicting a character as close in proximity to the viewer (i.e., "Close-Up") while simultaneously depicting asymmetry focused on or around the character's eyes (i.e., "Eye Asymmetry"). I will provide evidence supporting the idea that CUE-A is used in American comics to communicate the abject by comparing its use in depicting Batman (a Gothic superhero) with Superman (a non-Gothic superhero).

\section{THE ABJECT}

The abject "disturbs identity, system, order. What does not respect borders, positions, rules. The in-between, the ambiguous, the composite" (Kristeva 4). The behaviors of, and often the mere existence of, the abject character threatens to disrupt boundaries, both personal and societal. Because of this, the abject needs to be removed to preserve those boundaries (Skott 389). There are many features typical to the abject, including: (1) being interstitial or crossing boundaries, (2) its personification as monsters, (3) a lowly nature, (4) being threatening to the self and societal norms, and (5) needing to be rejected or destroyed.

\subsection{BEING INTERSTITIAL OR CROSSING BOUNDARIES}

In Gothic narratives, the abject is often portrayed as having certain characteristics, one of them being that it exists across boundaries. The abject refers to an admixed phenomenon (Hurley 144), that is to say a combination of characteristics that exist across borders from each other or at opposite ends of binarisms. Examples of Gothic characters that admix include the "wildman" (a human who crosses the boundary of civilized/savage), the "dog-faced boy" (admixing animal/human features), and the "hermaphrodite" (combining opposite ends of the male/female binary) (Hurley 139). It is important to note that the abject does not simply shift between categories or move along a binary, rather the abject exists in both categories simultaneously (Cavallaro 202).

\subsection{PERSONIFICATION OF THE ABjeCt As MONSTERS}

The Gothic monster can be considered a personification of the abject (Skott 390). Many monsters in Gothic horror are interstitial, occupying the spaces between categories, or contradictorily, embodying disparate categories at the same time (Caroll 32). Archetypal Gothic monsters often cross orthodox boundaries. These boundaries can include natural physical boundaries such as dead/alive (e.g., "undead" vampires, zombies) and animal/human (e.g. werewolves), or can also be societal boundaries, such as good/evil (e.g., Dr. Jekyll/Mr. Hyde, Frankenstein's monster). Gothic monsters are often both perpetrator and victim: they are dangerous and often violent, but they can also themselves be the victims of natural or social circumstances (Skott 390; Sothcott 443). As such, many Gothic monsters are manifestations of the abject (Cavallaro 202), with their transgressive behavior that rebels against societal norms often emphasized in Gothic narratives (Andrae “The Darkest Knight" 21). 


\subsection{A LOWLY NATURE}

Somewhat related to the idea of the Gothic monster as a personification of the abject, the nature or content of the abject is always loathsome or grotesque (Hurley 144), thereby giving the abject a lowly and/or miserable existence. The admixing that occurs in the abject often combines social ideals that are considered "high" (e.g., civilized, human, living) with those that are considered "low" (e.g., savage, animal, dead). This degradation of lofty ideals to a lower level is a feature of the grotesque (Hurley 138; Bakhtin 19), and a consequence of the admixing characteristic of the abject.

\subsection{BEING THREATENING TO THE SELF AND SOCIETAL NORMS}

By crossing boundaries and admixing binaries, the abject weakens the barriers between categories, threatening to destroy the borders keeping them separate. This weakening of borders, in turn, threatens our shared identity (cultural, national, and societal) as well as our sense of self (Skott 389). Indeed, the origin of the abject, deriving from a failure of abjection, comes directly from "abortive socializing processes" (Cavallaro 199). The failure of being socialized, this inability to be processed and categorized into agreed upon concepts and identities, undermines these crucial binarisms and categorical distinctions of society (Hurley 139).

\subsection{NEEDING TO BE REJECTED OR DESTROYED}

This threat to self and shared identity produces the need to reject or destroy the abject. Disgust for the abject leads to abjection, thereby causing the rejection of these subjects that cross the boundaries between categories (Conroy 106). As mentioned previously, in order to be accepted into society and take part in a shared identity, the individual must discard "everything which culture perceives as unclean, disorderly, asocial or antisocial." (Cavallaro 199). This discarding of the abject serves to protect the culturally shared ideas and concepts, the agreed upon boundaries and binarisms. This abjection even occurs at the level of selfhood, when the self, in an effort to maintain independence, must also be protected from the other. This can lead to the abjection of intimate attachments to assure the self-determination (i.e., independence, agency, individuality) of the self (Cavallaro 204).

\section{Possible Visual Metaphor for the Abject: Close-Up Eye Asymmetry}

\subsection{VISUAL METAPHOR}

In Gothic narratives, the abject nature of a character can be described using literal and/or metaphorical devices. In Gothic literature, an example of a literal device is a description of the physical body of an interstitial Gothic monster, like the werewolf, that crosses the boundaries of human/animal. An example of a metaphorical device could be having a character live in a dark and foreboding manor on the outskirts of town. While there is no boundary being 
crossed here (i.e., living in a manor is accepted by society), the metaphor is that concrete features of the manor, namely being "dark" and located on the "outskirts" of the town, map onto abstract features of the character, indicating that they are somehow also "dark" and "outside" of society.

Traditionally, metaphor was thought to be solely a linguistic or literary device. In contrast, conceptual metaphor theory proposes that this process of mapping similarities among concepts is a function of the human cognitive system (Lakoff and Johnson 159). As a cognitive process, metaphor can also be used in non-linguistic mediums such as pictures, producing visual metaphors, which can be used in Gothic narratives to communicate to an audience that a character is abject. One such possible visual metaphor is Close-Up Eye Asymmetry (CUEA).

\subsection{CLOSE-UP EYE ASYMMETRY}

CUE-A is a visual metaphor that is used extensively in the comic book medium (Juricevic 4). It consists of the combination of depicting a character as being physically close to the viewer (i.e., "Close-Up"), while simultaneously depicting asymmetry focused on or around the character's eyes (i.e., “Eye Asymmetry”). The cover of Detective Comics \#716 (December 1997) provides an example of CUE-A, with Batman shown as being close to the observer and asymmetry around Batman's eyes being caused by his scowled facial expression and shadows (see fig. 1 left panel). This can be contrasted with the cover of Action Comics \#676 (April 1992), which does not make use of the CUE-A visual metaphor. Here, while Superman is depicted as being close to the observer (though admittedly not as close as the Batman example), there is little to no asymmetry around Superman's eyes, even though he has a similarly scowled facial expression (see fig. 1 right panel).

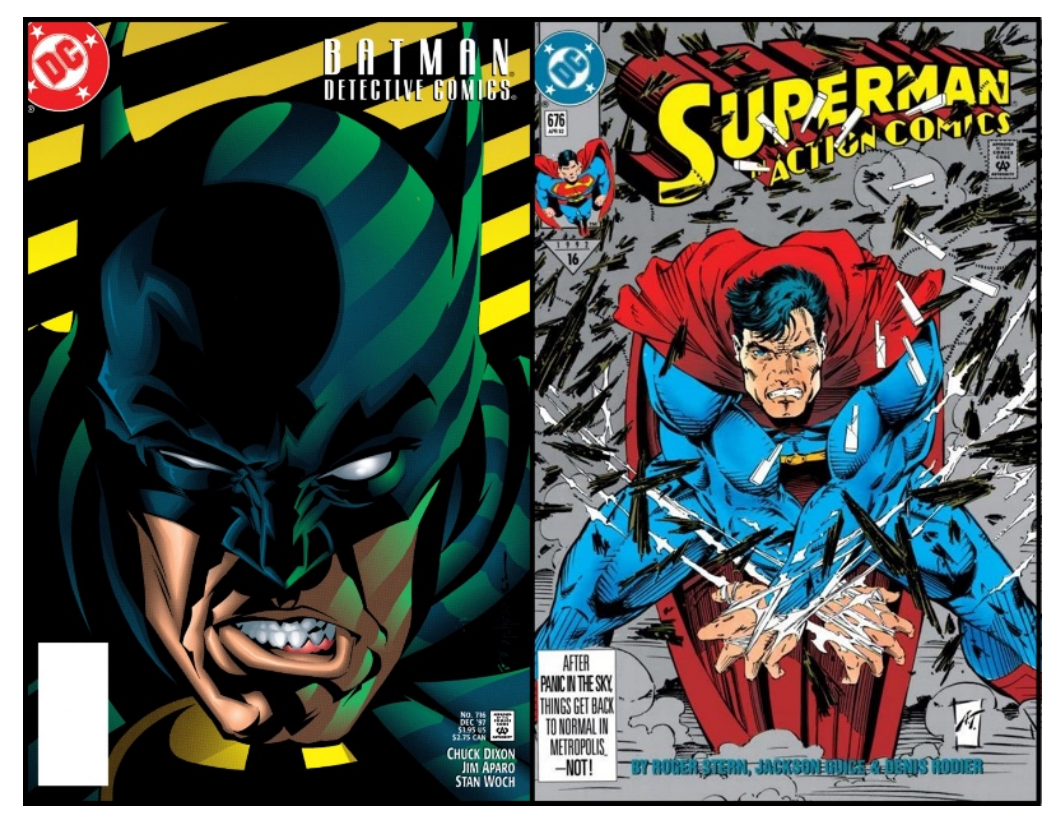

Figure 1

On the left, Batman depicted using CUE-A on the cover of Detective Comics \#716 (December 1997).

On the right, Superman on the cover of Action Comics \#676 (April 1992) is not depicted with CUE-A. 
Further examples of the use of CUE-A can be readily found in Batman's rogues' gallery (see fig. 2). These examples highlight the great variety of ways that CUE-A can be implemented, including by use of objects, facial disfigurement, hair and make-up, lighting, and character collage.

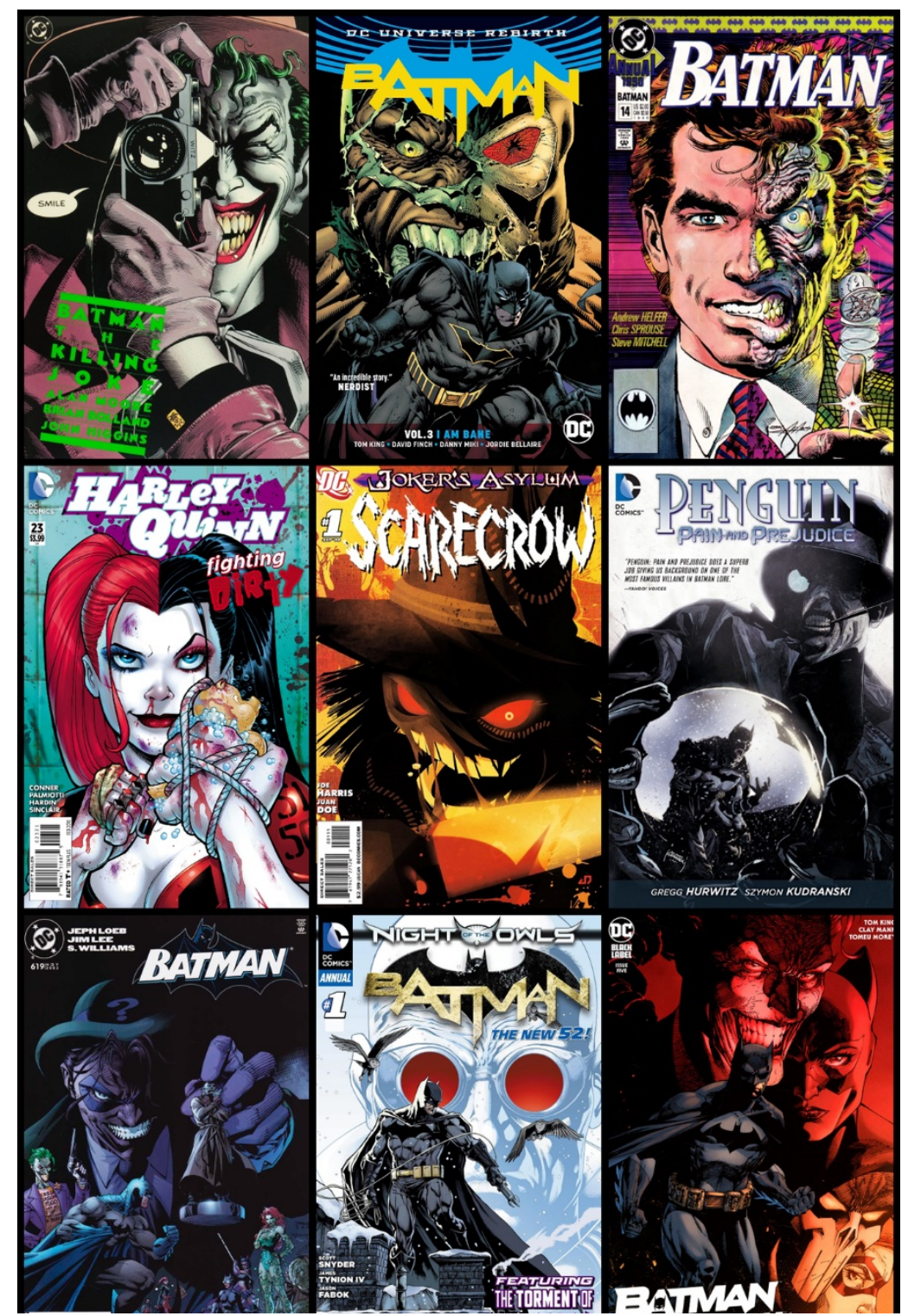

Figure 2 Some examples of how CUE-A can be implemented, including:

top: the Joker's camera (top left), Bane's torn mask (middle), Two-Face's disfigurement (right) center: Harley Quinn's hair and make-up (left), the Scarecrow's missing right pupil and shading (middle), the Penguin's monocle and shading (right)

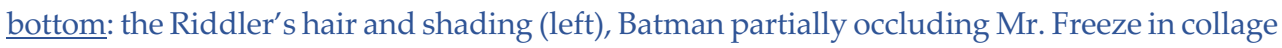
(middle), and the Joker partially occluding Catwoman in collage (right) 
If CUE-A can be understood as a visual metaphor, it must communicate different concepts about the depicted character. What are these concepts? An analysis of the structure of CUE-A using conceptual metaphor theory (Forceville 91) and visual design theory (Kress and van Leeuwen 3) reveals the nature of this visual metaphor.

First, let us consider conceptual metaphor theory. According to conceptual metaphor theory, a visual device can be metaphorical if the viewer experiences "one kind of thing in terms of another" (Lakoff and Johnson 5), such as experiencing action lines as path-of-movement indicators (Carello et al. 43). This experience often involves understanding abstract and/or complex phenomena in terms of concrete phenomena (Forceville 92). Applying conceptual metaphor theory to CUE-A suggests that the viewer experiences the concrete phenomenon of asymmetry to understand the abstract concept of other. Specifically, the literally represented asymmetry of a character's eye (the "Eye Asymmetry" part of CUE-A) is used metaphorically to communicate that the character is other (i.e., apart from human society, somehow not like the rest of us). This metaphor is understood by the viewer partly because our embodied minds (Johnson 100) have experienced, while living on Earth, bilateral symmetry in the majority of animals, human beings included (Finnerty 1174).

Additionally, symmetry is especially important in human faces. Neuropsychological research has shown that disfigured faces suppress both empathy and social cognition in the viewer, leading to the dehumanization of the disfigured individual (Hartung et al. 4). In other words, asymmetry in the face (in this research, through disfiguration) causes the disfigured person to be dehumanized (i.e., made other) by society. This dehumanization is, in effect, a perceived admixing of human and nonhuman categories, leading to the perception of the disfigured individual as interstitial. The suppressed empathy and social cognition further leads to the disfigured individual being easily judged as possessing an intrinsically evil nature and/or moral failings. As a result of this perceived admixing of high societal values (i.e., human) with low societal values (i.e., nonhuman/animal), the disfigured individual is judged as having degraded lofty ideals to a lower level, thereby becoming loathsome or grotesque (Hurley 144). In summary, according to conceptual metaphor theory, the abstract concept of other could be expressed in terms of the concrete concept of asymmetry, and this would be especially powerful for facial asymmetry.

An analysis of the visual design used in CUE-A leads to additional metaphorical interpretations. Specifically, the size of the image frame relative to the subject and their depicted physical distance are used to communicate the subject's kinship with the viewer. Analyzing the visual design structure of CUE-A indicates that we experience the concrete phenomenon of closeness to understand the abstract concept of kinship. Presenting the character at a close physical distance indicates that the character is inviting involvement from the viewer, that they are equal in power to the viewer, and a part of their world (Kress and van Leeuwen 125126). In other words, the literally represented physical closeness (the "Close-Up" part of CUEA) is used metaphorically to communicate that the character is akin to us (i.e., part of human 
society, somehow like the rest of us). In sum, according to conceptual metaphor theory and visual design theory, depicting a character using CUE-A implies that the character is simultaneously like the viewer (i.e., kinship) and also unlike the viewer (i.e., other), thus indicating that the character exists in these two categories at the same time.

\subsection{CUE-A COULd COMMUNICATE THE ABJeCT}

The conceptual metaphor theory and visual design theory analysis of CUE-A suggests that it is strongly positioned to communicate that a character is abject. As previously stated, the abject "does not respect borders, positions, rules" and is "The in-between, the ambiguous, the composite." (Kristeva 4). Further, the abject threatens the self and must be discarded, that is, made to be other (Cavallaro 199). As such, CUE-A could communicate the abject since it crosses the boundary of kinship/other, admixing these two opposite ends of the binary. Further, by combining these two opposite concepts, CUE-A threatens the integrity of the self, thereby requiring that it be discarded through abjection. In sum, the CUE-A visual metaphor is strongly positioned to communicate to a viewer that a character is abject.

\section{DOes CUE-A COMMUNiCATE THE AвJECT?}

Even though CUE-A could communicate the abject, is it actually used in this way? And, if so, is it actually used in Gothic narratives? The purpose of this study now turns to determining if CUE-A is used to communicate the abject in Gothic narratives. To test this, I looked at whether the CUE-A visual metaphor is used more extensively in American comics in which Gothic modes are pervasive compared to those which lack Gothic features. Specifically, I analyze the use of CUE-A in comics featuring Batman (which make pervasive use of Gothic modes) versus those featuring Superman (which contain very few, if any, Gothic features). The argument underlying this study is as follows:

Premise 1: Batman is more Gothic than Superman

Premise 2: Batman is more abject than Superman

Premise 3: Batman is depicted with CUE-A more often than Superman

Conclusion: CUE-A is used to communicate the abject in Gothic narratives.

\subsection{PREMISE 1: BATMAN IS MORE GOTHIC THAN SUPERMAN}

While it may be difficult to define what is or is not Gothic consistently (Round 11), there are elements that are characteristic of the Gothic theme. Representative Gothic characteristics include, but are not limited to, the pervasive presence of fear, the monstrous, the other, the uncanny, the constant infringement of the past into the present, as well as oppressive architecture (Jensen 92) and the erosion of boundaries (Skott 387). The general consensus is that Batman is a Gothic character. Batman is considered to be "the first major gothic superhero in 
comic books" (Andrae "The Darkest Knight" 19), with a definite "Gothic sensibility" (Fitch 208). Batman's mythos is "about the pressing of Gothic Fear into the service of heroic Justice" (Fisher), thus making "Batman's story... truly a gothic one" (Jensen 92).

Even though Batman is considered to be a Gothic character, the rational for this study requires that Batman also be "more Gothic" than Superman. In other words, this study requires that the tropes fundamental to the Batman mythos contain more Gothic features than the Superman mythos. To this end, Batman can essentially be viewed as the Gothic double of Superman's straightforward superhero ideal (Monnet 96). In fact, Batman can be thought of as a Gothic reaction to the enlightened ideals that Superman represents (Bukatman 205). That Batman is actually more Gothic than Superman can be further demonstrated by analyzing various aspects of both characters, and highlighting how Batman's character uses more of the commonly recurring Gothic narrative devices and themes than Superman's.

First, Batman's visual appearance is more Gothic than Superman's (see fig. 3). Batman's look was based on a staple character of Gothic narratives, the vampire (Andrae "The Darkest Knight" 23-24). Batman's costume was specifically designed to "strike terror into their [criminals'] hearts" (Finger and Kane). Terror is a basic element of Gothic narratives (Skott 387). This element of terror combined with the similarities to vampires gives Batman's costume "an inherent Gothic sensibility to it" (Fitch 208). On the other hand, Superman's brightly colored costume was inspired by classical heroes and performing strongmen (Andrae "Of Supermen" 14), with the "S" insignia variously standing for "Superman" (Andrae "Of Supermen" 14), "Hope" (Waid), and "Stronger Together" ("Stronger Together").

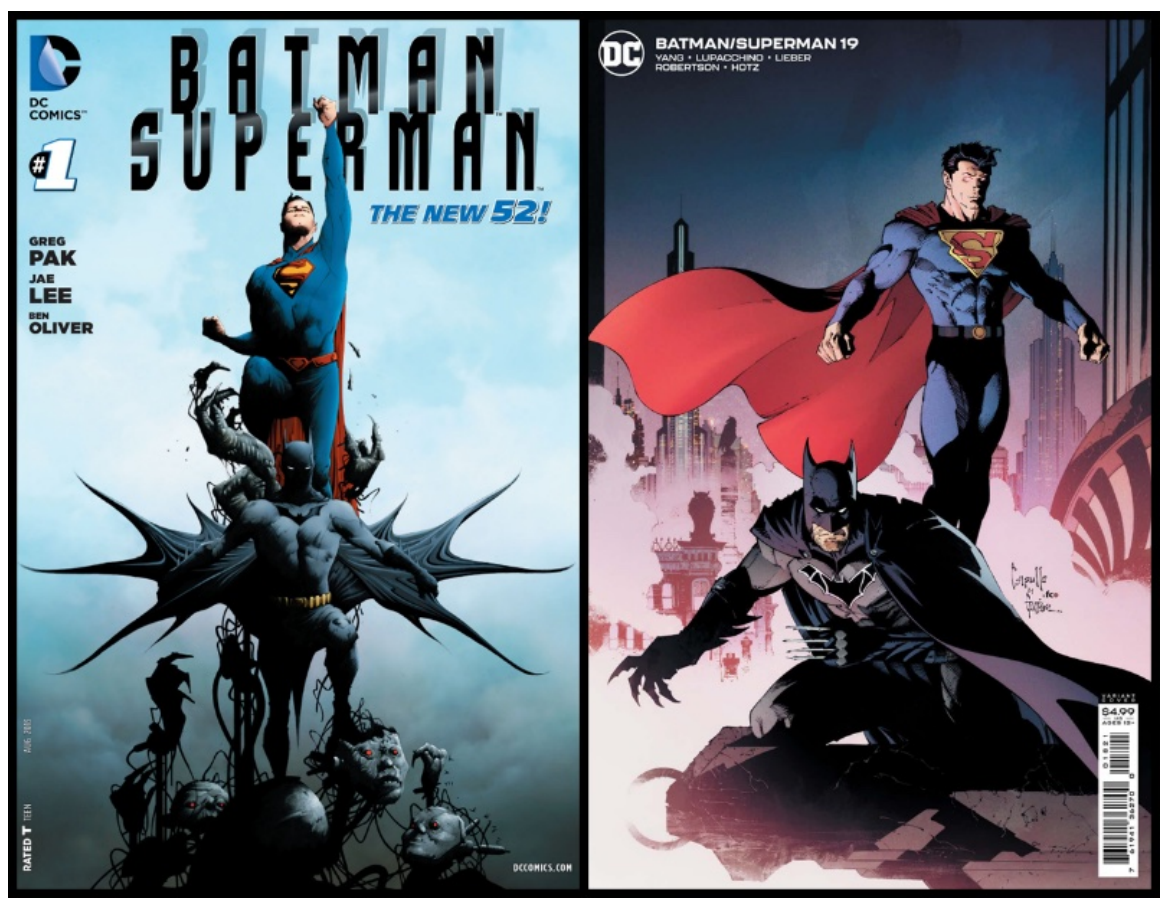

Figure 3 Batman and Superman depicted together on the covers of Batman/Superman \#1 and \#19.

On both covers, Superman's costume is brightly colored and he is positioned in the light, while Batman's costume is darkly colored and he is positioned in the shadows. The Gothic vampire influences on Batman's costume are especially prominent given the use of dramatic shadows (left) and how Batman is holding his Batarangs to give the appearance of claw-like hands (right). 
Second, Batman's origin story is more Gothic than Superman's. Batman's origin story revolves around the murder of his parents when he was a young boy, which is a Gothic theme as "Gothic tales often linger on the characters' memories of a traumatic and shattering encounter" (Bruhm 268). The trauma from the murder of his parents is continually returned to and has become part of the basic psychology of Batman (Sanna 34). Batman's memories often linger on the murder of his parents, revisiting this tragedy in comics, animated cartoons, and movies. In contrast, Superman's memories rarely linger on the death of his Kryptonian birth parents, whom he did not grow up with. Furthermore, while his adoptive father died in Action Comics \#870 (December 2008), 69 years after Superman's debut, his mother is still very much alive and a guiding influence on him.

Third, the spaces that Batman inhabits are more Gothic than those Superman inhabits, including Gotham City, Wayne Manor, and the Batcave. Batman protects Gotham City, while Superman defends Metropolis. The characterization of Gotham City further links Batman to the Gothic genre (Sanna 35). In fact, Gotham City is a "liminal city" that is "indicative of the urban Gothic" (McCrystal 316, see fig. 4, left panel). Extending its Gothic aesthetic, Gotham City is described as containing "Gargoyles to frighten people onto the path of righteousness, rounded edges to confuse the malevolent beings, thick walls to lock in virtue' (Grant and Breyfogle 20-21). This is in direct opposition to the superior quality and more modern cityscape of Metropolis with its "orientation towards the future not the past" (Cremers 144, see fig. 4, right panel). Indeed, Gotham City is the dark Gothic reflection of the bright and ideal Metropolis (Fitch 214).

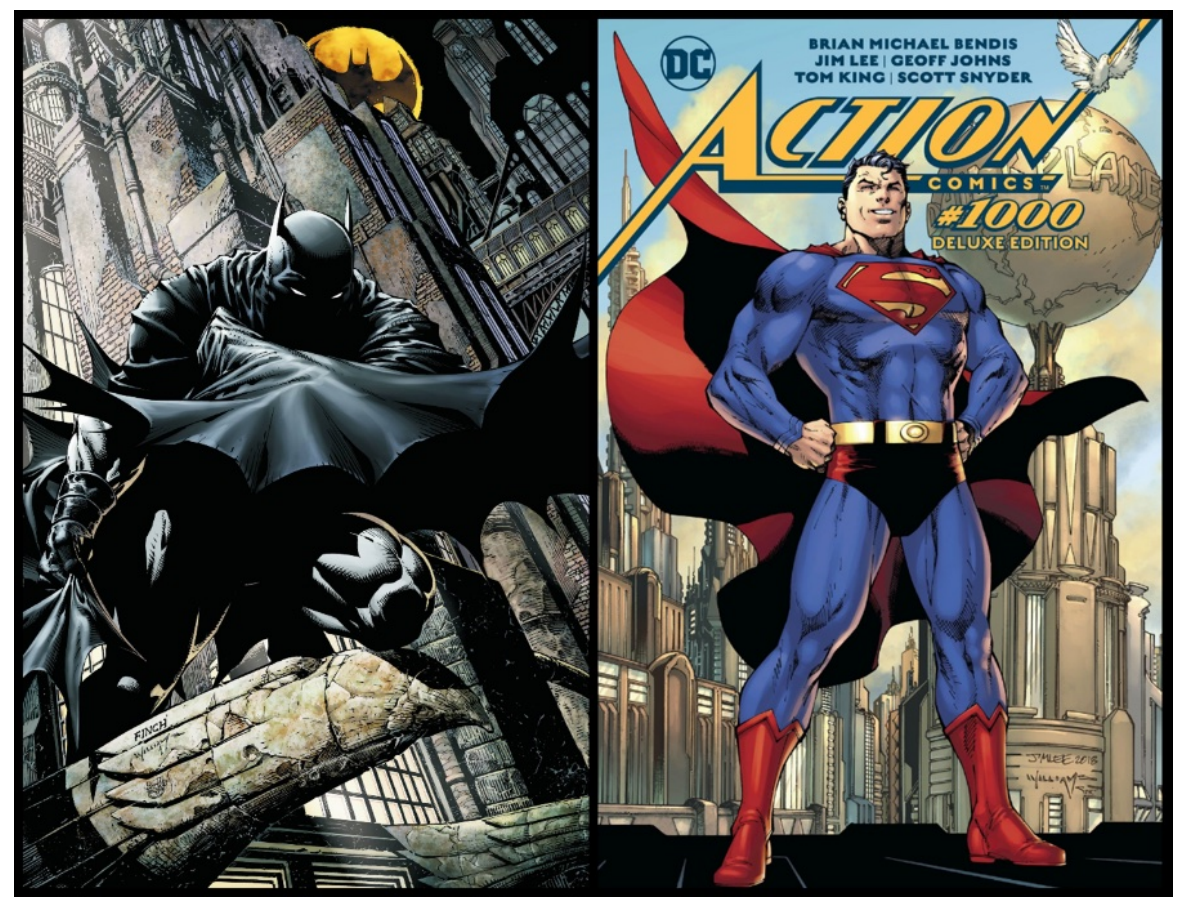

Figure 4

On the left, Gotham City's Gothic features include dark shadows, gargoyles, and crumbling edifices.

On the right, Metropolis is depicted as a much more modern city, with a brighter and more vibrant skyline. 
Batman's civilian residence is Wayne Manor, an ominous, opulent mansion located on the outskirts of Gotham City (Knox, see fig. 5, top left panel). Wayne Manor is 150 years old, and usually depicted with characteristic Gothic elements such as dark hallways, towering libraries, shadowy recesses, and even a vast array of caverns underneath the mansion (i.e., the Batcave, discussed below, see fig. 5, top right panel). As mentioned previously when discussing metaphors in literature, the concrete features of Wayne Manor, namely being "dark" and located on the "outskirts" of the town, map onto abstract features of Batman, indicating that he is also somehow "dark" and "outside" of society. Once more, this can be contrasted with Superman's non-Gothic civilian residence, an apartment in a high-rise complex located at 344 Clinton Street in the heart of Metropolis ("344 Clinton Street", see fig. 5, bottom left panel). An even greater contrast is found in Superman's more recent apartment that he shares with Lois Lane, with its open concept and abundant natural lighting (see fig. 5, bottom right panel).

Figure 5

Top: Wayne Manor's exterior (left) and interior room (right).

Bottom: Superman's original apartment's exterior (left) and a view of his and Lois' new apartment's interior (right).

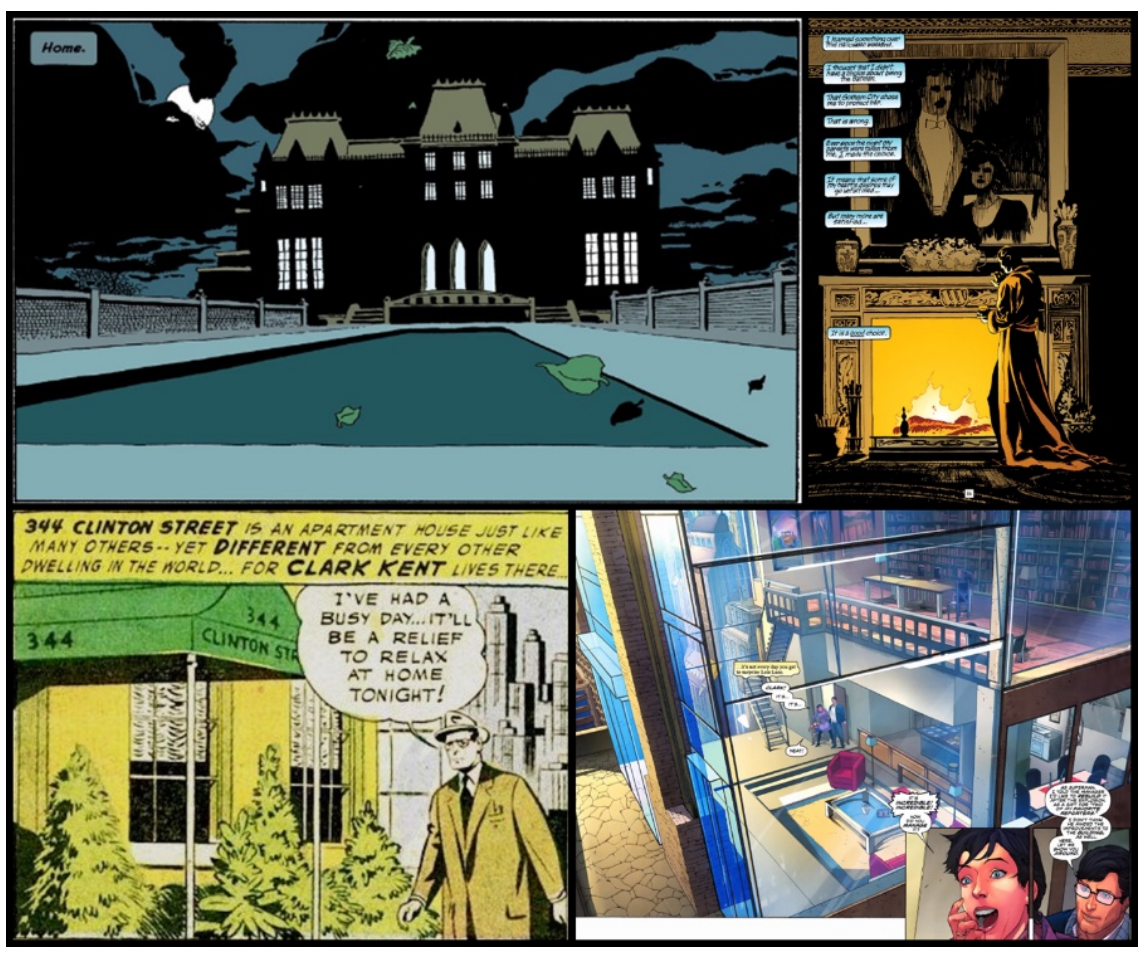

Batman's superhero headquarters, the Batcave, is "inherently Gothic" (Fitch 207). It is a space that admixes the ancient and the new, combining "rocky walls and a state-of-the-art crime laboratory" (Reinhart 20, see fig. 6, left panel). Even its location incorporates classic Gothic elements, being analogous to a gloomy dungeon located under a Gothic castle (Wayne Manor). This is in direct opposition to Superman's superhero headquarters, the Fortress of Solitude. The Fortress of Solitude is a glittering structure, housing advanced, crystal-based technology from Krypton (see fig. 6, right panel). It is also located somewhere in the lofty summits of the Arctic Mountains, rather than in the depths of an underground cave. 


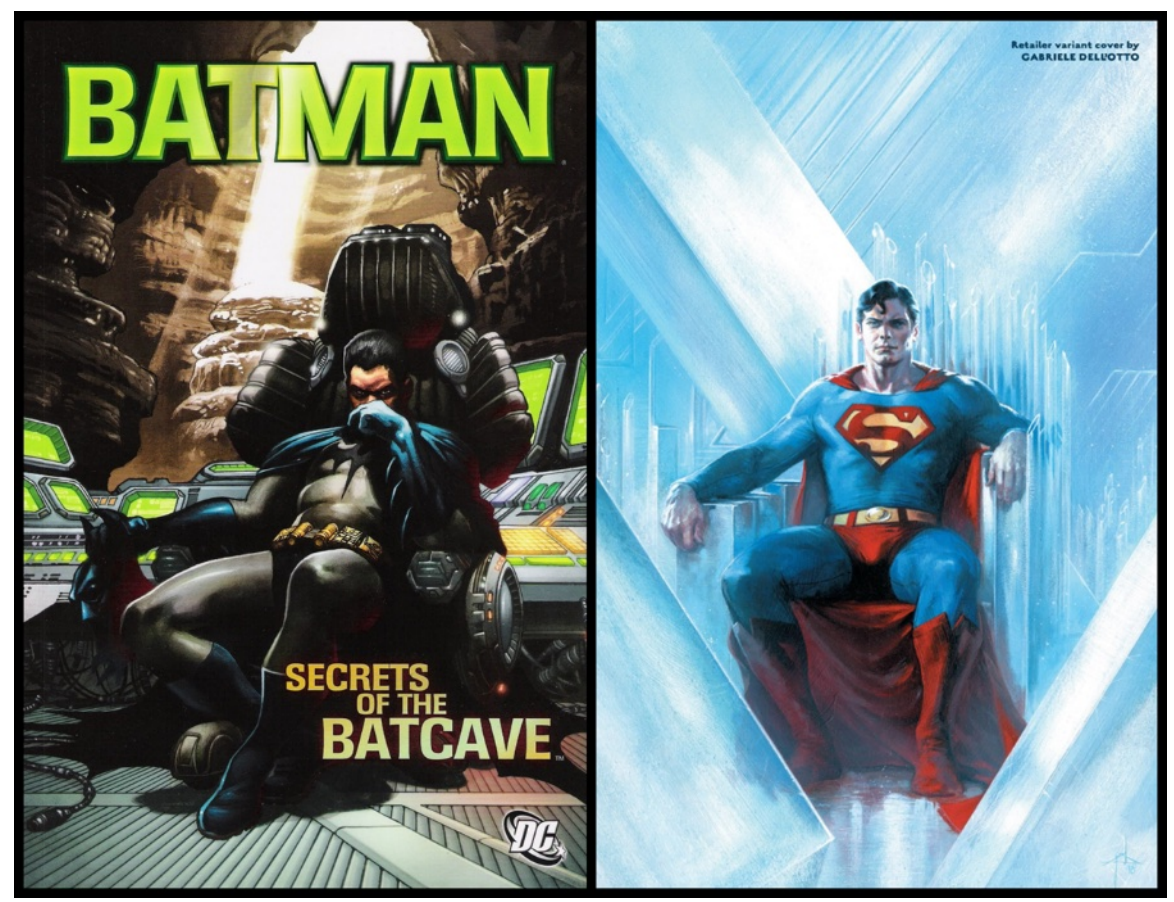

Figure 6

On the left, Batman seated at his computer in the Batcave.

On the right, Superman seated at his Kryptonian computer in the Fortress of Solitude.

Finally, even Batman's rogues' gallery is more Gothic than Superman's (see fig. 7). "The Gothic mode has also been, from Batman's beginning, particularly present in the recurring villains of the series" (Monnet 102). Writers and artists created sympathetic villains for Batman who were themselves also victims (e.g., the Joker, Bane, the Penguin, and Two-Face), a common theme for Gothic villains (Andrae "The Darkest Knight" 29). Given that Batman's crime fighting motivations also stem from past trauma, this further serves to blur the boundaries between good (the hero Batman) and evil (his rogues' gallery). Many of Batman's rogues exemplify the Gothic mode by being physically deformed (e.g., Clayface, Killer Croc), mentally deranged (e.g., the Mad Hatter, the Ventriloquist), or having grotesquely disfigured faces (e.g., the Joker, Two-Face) (Monnet 102). Delving further into Gothic motifs, many of Batman's villains are creatures "utterly different from normal man: a vampire, an atavism, a degenerate, closer to apes and savages and rodents" (Skott 386), such as Killer Croc or one of Batman's earliest foes, the vampire/werewolf Monk (Andrae "The Darkest Knight" 21). These characteristics of Batman's rogues differ greatly from Superman's. Superman's villains tend to be less physically deformed or grotesque (e.g., the entirely human Lex Luthor, or Superman's fellow Kryptonian, General Zod). Even Superman's alien villains that deviate from a human appearance tend to be less composite and more completely alien, not crossing boundaries between human and alien (e.g., Brainiac, Darkseid, Doomsday). 


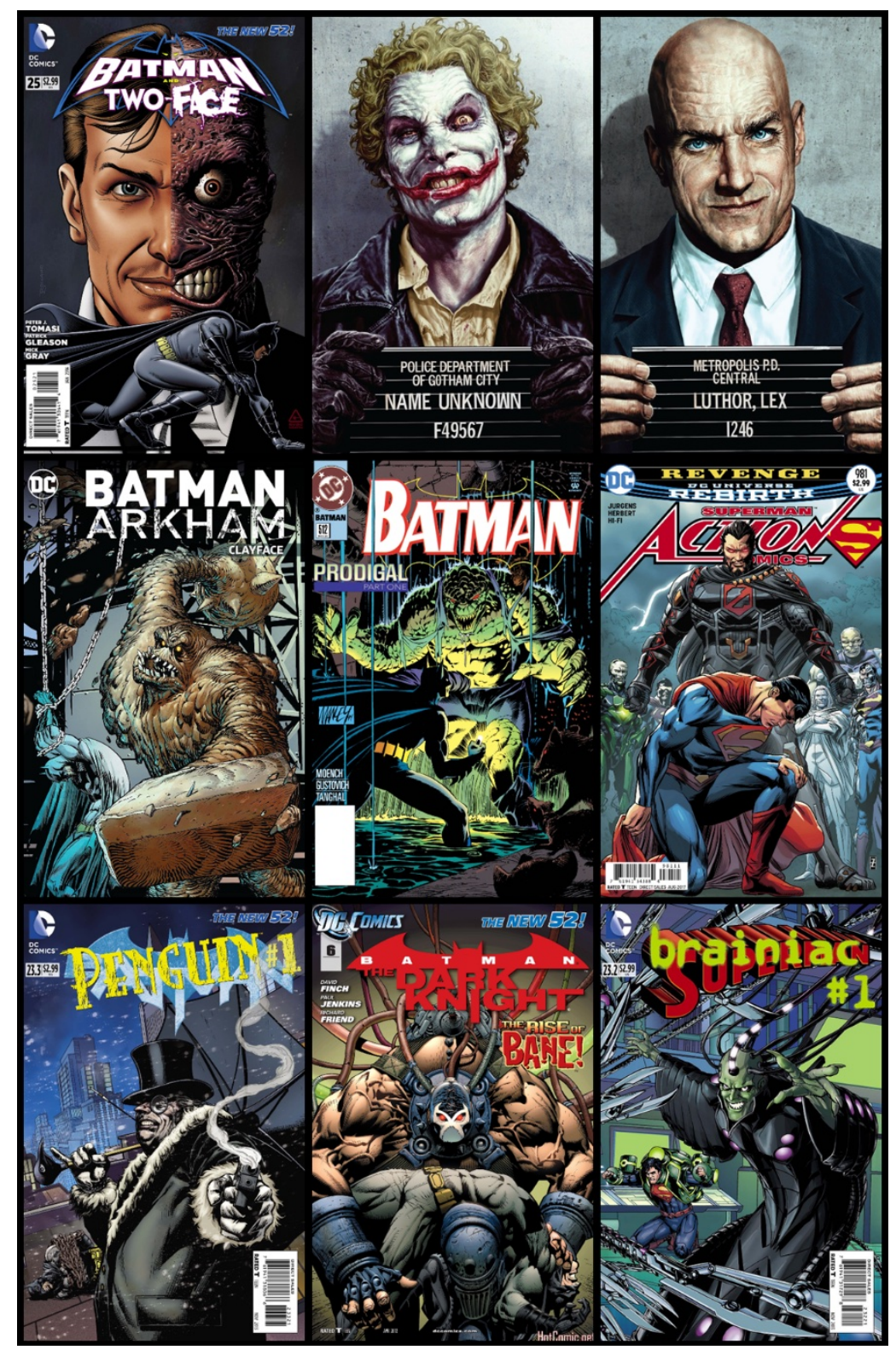

Figure 7

Batman's villains tend to have grotesquely disfigured faces (Two-Face and the Joker, top left and center) compared to Superman's villains (Lex Luthor, top right).

Batman's villains tend to be physically deformed (Clayface and Killer Croc, middle left and center) compared to Superman's villains (General Zod, middle right).

Batman's villains are often themselves also victims (the Penguin and Bane, bottom left and center) compared to Superman's villains (Brainiac, bottom right).

\subsection{PREMISE 2: BATMAN IS MORE ABJECT THAN SUPERMAN}

After demonstrating that Batman is Gothic and, importantly for our purposes, unquestionably more Gothic than Superman, the next step in the argument is to show that Batman is more 
abject than Superman. An abject character is one that "disturbs identity, system, order. What does not respect borders, positions, rules. The in-between, the ambiguous, the composite." (Kristeva 4). Previously, several characteristics of the abject were enumerated, which are now recalled to show that Batman possesses these characteristics to a greater extent than Superman.

\subsubsection{Being Interstitial or Crossing Boundaries}

Batman's character is defined by his "tensions and paradoxes" (Monnet 99), crossing boundaries across a variety of dimensions. For example, Batman is a hero but also an outlaw, often accepted as an honorary member of the police force while still engaging in illegal vigilante actions (Andrae "The Darkest Knight" 28). And even though Batman's actions are illegal, they are paradoxically dedicated to the return of law and order to Gotham (Sanna 42). On the other hand, although Superman also engages in vigilante actions, he remains respectful of the law and attempts at all times to comply with authorities (Nicolas 15-16). Superman can be thought of as a part of the American justice system, fighting for "truth, justice, and the American way" (Wandtke 178).

Batman is often suggested to also cross sexual and romantic boundaries. Questions surrounding Batman's sexuality have persisted throughout his publication history. This has often occurred because of Robin (Monnet 100), with questions arising whether the nature of their relationship is sexual/platonic, heterosexual/homosexual, and legal/illegal (Dick Grayson was 10 years old when he became Robin). This similarly occurs in Batman's complex relationship to the Joker, who has at times referred to Batman as "darling" and "my sweet" ("Batman: The Dark Knight Returns", Miller 141, 150), and outright admitted that he loves Batman ("Batman: Death of the Family", Nocenti and Sandoval 92). No such questions arise regarding Superman's sexuality, as his heterosexual relationship with Lois has been a stable part of his publication history.

Batman's appearance also crosses boundaries, "most notably (and alarmingly) breaking down the distinction between human and inhuman, human and animal." (Hurley 137). Even his name, "Batman", suggests the crossing of the animal/human binary (Fisher). Superman's name suggests no such crossing of boundaries, but rather the peak fulfillment of humanities greatest ambitions (Wandtke 56). Further, Batman even crosses his own boundaries, having changed in his presentation over the years "between dark and light versions, intensely alone and sometimes slightly mad (dark version), or playful and energetic as he dance/fights alongside his young sidekick (light version)." (Monnet 101). Superman's appearance, in comparison, has remained relatively stable throughout his publication history, with very brief changes made for specific storytelling purposes (e.g., his Black suit to aid his recovery in the "The Return of Superman" story arc, Stern and Guice 11). 


\subsubsection{Personification as a Monster}

Batman is essentially a Gothic monster. As mentioned previously, the Gothic monster can be seen as a personification of the abject (Skott 390), with many monsters in Gothic horror being admixed (Caroll 32). The admixed nature of Batman (i.e., mixing human/animal) suggests his monstrous character. In fact, in his own mythos, Batman is a self-created Gothic monster (Fisher), assuming the appearance of a hostile, supernatural creature (i.e., the vampire, Sanna 38; Andrae "The Darkest Knight" 23-24). Batman even employs the tactics of a horror monster, attacking at night and from the shadows (Sanna 39). Finally, Sara Skott observed that "The monster, in the Gothic imagination, is representative of social traumas, for which it is also blamed." (389). This is undoubtedly true for Batman, for not only is his origin tied directly to the murder of his parents (i.e., social traumas), but Batman is often blamed for the proliferation of costumed villains in Gotham City. Superman, by contrast, was not based on monsters but rather on epic heroes such as Samson and Hercules (Wandtke 58). He is the complete opposite of a Gothic monster, representing instead the realization of human perfection (Nicolas 122).

\subsubsection{A Lowly Nature}

Batman has an inherently lowly nature, especially when compared to his fellow superheroes. The nature of the abject is always loathsome or grotesque (Hurley 144), and Batman modeled his appearance on a bat, bringing the high ideal of the costumed superhero low by admixing it with what is typically thought of as a loathsome creature. On the other hand, Superman's appearance was modeled on the American flag, suggesting a merging of Superman's ideals with what is best about America (Gordon 41). "Superman stood for civility, tolerance, and the struggle to extend just who was tolerated." (Gordon 48). Batman himself is often reminded by friends and foes that he is simply a human with no superpowers. His very categorization as a superhero crosses the boundary regularly used to define "superhero". The Oxford Languages dictionary defines "superhero" as "a benevolent fictional character with superhuman powers, such as Superman." "Definition of superhero in English"; emphasis added). Batman is merely a man, infusing a lowly nature into the heroic physical ideals of super men and wonder women. Superman, by contrast, is the very personification of those heroic physical ideals (Nicolas 122).

\subsubsection{Being Threatening to the Self and Societal Norms}

Batman's behavior and mere existence threatens the integrity of the self and societal norms. As mentioned previously, the abject weakens the borders of the self and societal norms. Batman, as the result of "abortive socializing processes", can be regarded as a failure of abjection (Cavallaro 199). Batman's ethics and methods are often described in shades of gray (Cates 834). His vigilante actions are in service to himself, rather than to the law: "For Batman, on the other hand, law enforcement authorities are tools in his war on crime. Like any tool, they are 
to be used when needed and laid aside when they aren't." (Nicolas 16). Conversely, Superman, even when engaging in vigilante actions, attempts to comply with authorities whenever possible (Nicolas 15-16). Superman avoids the assumption that might makes right, and strives to be observant of the law whenever possible (Nicolas 48).

Further, "Bruce Wayne's alter ego [Batman] is intentionally constructed as the "Other", whose presence only apparently threatens to disturb the boundaries of civilization and rationality" (Sanna 33). Conversely, Clark Kent's alter ego (Superman) is constructed as representing the best of America (Gordon 41), fully integrating himself into American society and providing that society an inspirational example to strive for. By crossing boundaries and admixing binaries (hero/outlaw, human/animal, self/other), Batman's existence and behaviors weaken the walls between categories, threatening our shared identities (cultural, national, and societal) and our sense of self (Hurley 139; Skott 389). Superman's existence helps to shape and articulate our societal categories, especially for "truth, justice, and the American way" (Gordon 48).

\subsubsection{Needing to be Rejected or Destroyed}

It has already been argued that Batman both appears and behaves as a Gothic monster and, as such, is a threat to self and shared identity. The Gothic monster is unique from other forms of othering in Gothic narratives in that the monster must be destroyed (Skott 390). This feature of the abject, the requirement to be rejected or destroyed, is readily present in Batman. Batman is a vigilante, engaging in illegal activities, and has more than once been pursued by the police (Andrae "The Darkest Knight" 24). He lives in Wayne Manor, on the outskirts of Gotham City, apart from society (Knox). Even further, Batman spends much of his time alone in the Batcave. Batman has even been cast out of the Justice League for his actions (he was voted out of the Justice League following the events of "Tower of Babel", Waid and Hitch 2). Superman, on the other hand, represents "truth, justice, and the American way" (Wandtke 178). He lives in the heart of Metropolis, often cohabiting with Lois Lane. Lastly, Superman has never been voted out of the Justice League, rather he was the deciding vote that cast out Batman (following the events of "Tower of Babel", Waid and Hitch 2).

\subsection{Premise 3: BAtMAn is Depicted With CUE-A More OfTEN THAN SUPERMAN}

Now that the Gothic and abject nature of Batman in comparison to Superman has been established, the penultimate step in the argument is to show that the CUE-A visual metaphor is used to depict Batman more often than Superman.

\subsubsection{Method}

A corpus analysis of comic book covers was completed to determine if CUE-A is used to depict Batman more often than Superman. Specifically, I analyzed the covers of both Detective Comics and Action Comics and identified instances where Batman or Superman, respectively, were 
depicted using CUE-A. The covers selected spanned four decades from January 1960 to December 1999. The issues released during the selected period were Detective Comics \#275-739 and specially numbered issues \#0 and \#1000000, and Action Comics \#260-600 and \#643-760. Action Comics \#601-642 were excluded from the corpus analysis because they were rebranded as Action Comics Weekly and featured a variety of characters from the DC universe other than Superman. The selected dates ensured that the covers used in the corpus analysis: (1) spanned multiple American comic book ages (i.e., Silver Age 1956-1970, Bronze Age 1970-1985, and Modern Age 1985-Present), (2) featured a variety of different authors and artists on each book, and (3) included Batman's more Gothic period in the late 1960s and 1970s (Monnet 97).

For the analysis of the covers, "Close-Up" was operationally defined as a depiction of a character at a distance such that their entire body could not be visible in the frame of the image (see fig. 1). Note that this excluded instances when parts of the character's body would have been visible if they were not occluded (e.g., the character is distant but partly hidden behind a building) or were not out of frame. "Eye Asymmetry" was operationally defined to have occurred when both eyes were potentially visible (i.e., side profiles did not count as "Eye Asymmetry"), but one eye was either obscured (e.g., by hair, eye patch, etc.) or clearly depicted differently than the other eye (e.g., heavier shading, black eye, etc.).

Using these operational definitions, I reviewed the 467 Detective Comics covers and the 459 Action Comics covers for instances where Batman or Superman, respectively, were depicted using the CUE-A visual metaphor. Only depictions of Batman or Superman were used for this corpus analysis, no other characters were included.

\subsubsection{Results}

Covers of Detective Comics were given a score of " 1 " if they contained Batman and he was depicted using CUE-A. Covers were given a score of " 0 " if they contained Batman but he was not depicted using CUE-A. Lastly, covers were not included in the statistical analysis if Batman was not depicted on the cover. The analogous scoring system was used for Superman in Action Comics.

Of the 467 Detective Comics covers analyzed, 441 (94.4\%) depicted Batman. Of these 441 covers, 29 (6.6\%) depicted Batman using CUE-A (see fig. 8). Of the 459 Action Comics covers analyzed, 443 (96.5\%) depicted Superman. Of these 443 covers, 17 (3.8\%) depicted Superman using CUE-A (see fig. 8). 


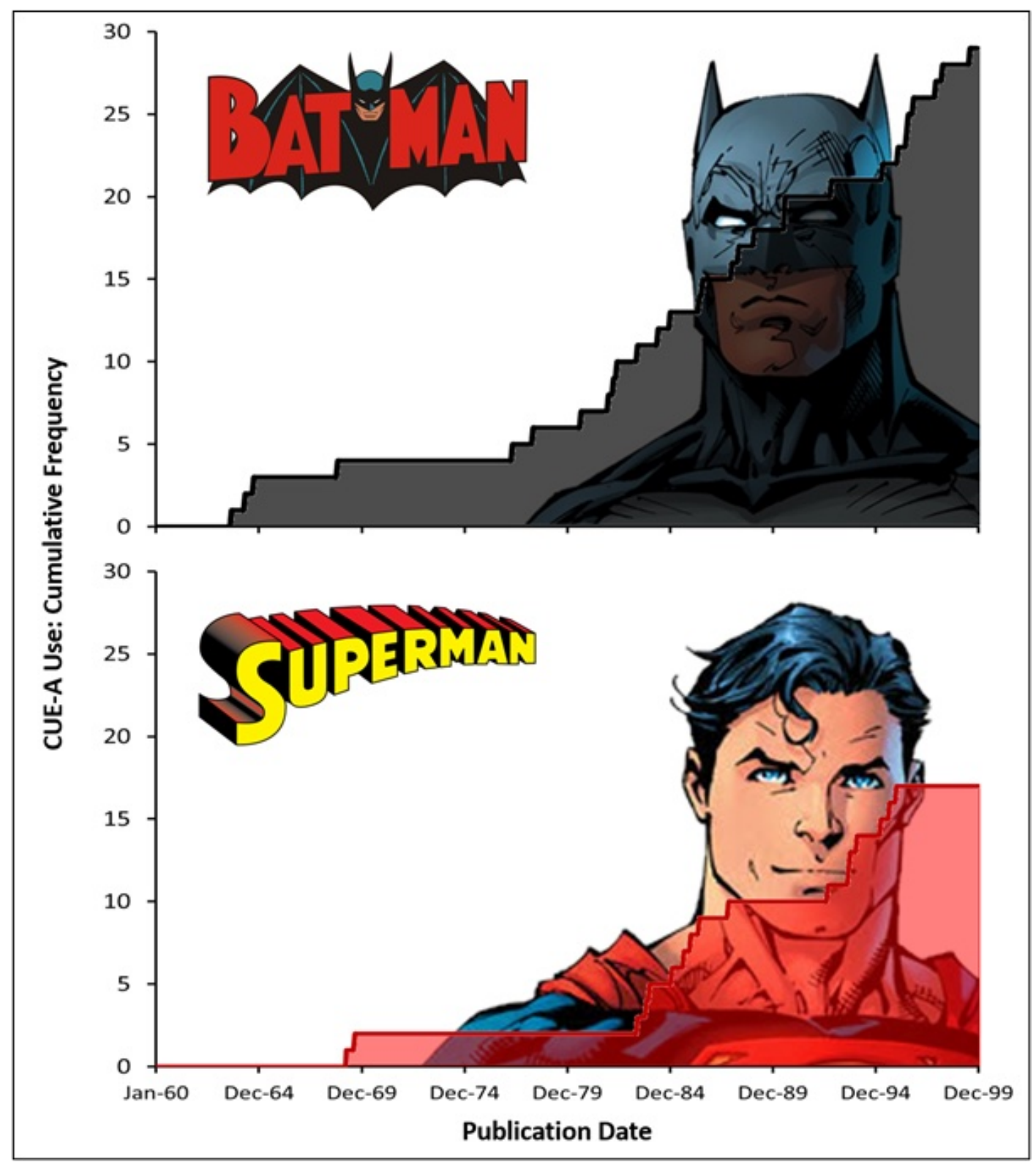

Figure 8

Cumulative frequencies for the use of the CUE-A visual metaphor when depicting Batman in Detective Comics and Superman in Action Comics.

Top: Batman image taken from: Snyder, Scott and Tom King, writers, and Jim Lee, cover artist. Batman: Rebirth. Vol. 1, no. 1, Convention Exclusive Variant Cover, DC Comics, Aug. 2016. Batman logo from: Babies, Bronze Age. "Which Batman Logo Would You Prefer? Pic.twitter.com/hfjRN76NMf." Twitter, Twitter, 12 Dec. 2017, twitter.com/bronzeagebabies/status/940402140555743232.

- Bottom: Superman image taken from: Tomasi, Peter and Patrick Gleason, writers, and Jim Lee, cover artist. Superman: Rebirth. Vol. 1, no. 1, Convention Exclusive Variant Cover, DC Comics, Aug. 2016. Superman logo from: "Superman Logo The New 52, the Title Bar Design, Heroes, Text, Trademark Png." PNGWing, www.pngwing.com/en/free-png-yxqpr. 
These scores were tested using a one-tailed independent means $t$-test. The $t$-test assessed if the difference found in the use of CUE-A is a real and reliable difference. It accomplishes this in a somewhat backwards manner, by actually calculating the probability that random variation caused the predicted higher use of CUE-A for Batman. In other words, it is possible that the difference in CUE-A use found in this study, 29 for Batman vs. 17 for Superman, was simply a lucky outcome and does not reflect how an abject character such as Batman is depicted in Gothic narratives. The $t$-test, however, indicated that there is only a $3.4 \%$ chance that these results are due to chance, $t(882)=1.8, p=.034$. In other words, it is highly unlikely that the greater use of CUE-A for Batman compared to Superman is a lucky, random outcome. This, in turn, makes it highly likely that the greater use of CUE-A for Batman compared to Superman is a real and reliable difference.

\section{CONCLUSION: CUE-A COMmunicAtes the AbJeCt in Gothic NARRATIVES}

The statistical analysis revealed that Batman is depicted using CUE-A more often than Superman. Given that Batman is portrayed with more Gothic and abject features than Superman, this supports the idea that the CUE-A visual metaphor communicates the concept abject in Gothic narratives. In other words, in a Gothic narrative, depicting a character as close to the viewer and with some sort of asymmetry about the eye could inform the viewer that the character is abject.

\subsection{CUE-A USE INCREASES DURING GOTHIC ERAS}

Even though it was not explicitly tested in this study, further evidence that CUE-A communicates the abject can be found in how the use of CUE-A has increased over time. During the years included in the corpus analysis (1960-1999), there was a rapid increase in the use of the CUE-A visual metaphor when depicting Batman in two separate periods. The first occurred in the mid-70s and the second in the mid-90s (see fig. 8). The increase in the mid-70s coincided with "Batman's Gothic turn in the late 1960s and 1970s" (Monnet 97), when writer Dennis O'Neil and artist Neil Adams transitioned Batman away from the lighter, campier attitude that dominated the 50s and early 60s to a darker, more Gothic aesthetic (103). The second increase in CUE-A use, occurring in the mid-90s, coincided with the comic book's adoption of the Gothic aesthetic found in director Tim Burton's and artist Anton Furst's designs for the film Batman (1989). Tim Burton brought an extensively Gothic aesthetic to his work, having been heavily influenced by European fairytales and horror films (Fitch 208). Furst further articulated this aesthetic in his set designs for Gotham City. Burton's European fairytale influences helped to produce a more complex and ambivalent Batman (Hart 4), influencing Batman's portrayal in the comics. Furst's set designs for the Batman film heavily influenced the appearance of Gotham in the comics between 1992 and 1998 (Fitch 213). The influence of Furst's work was so great that some of his sketches for the Batman film were used as the 
background art for covers of Batman comic books (Fitch 209). This augmented Gothic aesthetic in the Batman comics also served to produce a more Gothic tone to the stories written at that time (Fitch 213-214).

Surprisingly, there are also two periods where there was a rapid, although smaller, increase in the use of the CUE-A visual metaphor when depicting Superman. The first occurred in the early 80 s and the second in the early 90 s (see fig. 8). This may have been be due to Gothic influences on Superman's stories as well. Superman went through a reinvention in the early 80s, with the "final story" of the Golden Age Superman taking place in "Whatever Happened to the Man of Tomorrow?" (September 1986) written by Alan Moore, and Superman's reboot by John Byrne in “The Man of Steel” (July-September 1986). This may have shifted Superman's aesthetic to a more Gothic tone, as the character crossed between the boundaries of "death" (i.e., of the Golden Age Superman) and "rebirth" (i.e., into the Modern Age). Likewise, the second increase in CUE-A use, occurring in the early 90s, corresponded to another Superman "death", this time at the hands of Doomsday in the "Death of Superman" storyline (1992-93). Superman then returned once again (i.e., "rebirth") in "The Return!" (1993). Given the Gothic nature of admixing the dead and the living, the increased use of CUE-A to depict Superman during these two periods may have been directly caused by the more Gothic nature of those stories.

\subsection{FUTURE RESEARCH}

This is the first study to provide evidence that CUE-A can be used as a visual metaphor for the abject in Gothic narratives. Further research is needed to determine if this finding generalizes across different Gothic mediums and narratives. Possible avenues for future research include: (1) other Gothic comic book characters in the superhero genre (e.g., DC's Deadman, Marvel's Moon Knight), (2) other Gothic comic book characters in other genres (e.g., DC's Dream from the Sandman comic, Roman Dirge's Lenore from Lenore, the Cute Little Dead Girl), (3) Gothic film (e.g., Sleepy Hollow [1999], The Witch [2015]), and (4) Gothic still art (e.g., Henry Fuseli's The Nightmare [1781], C. Allan Gilbert's All is Vanity [1892]).

Another question that the current study raises stems from the co-occurrence of CUE-A with Gothic narratives and the abject. This co-occurrence leaves open the possibility that: (1) CUE-A also communicates the abject outside of the Gothic genre, (2) CUE-A communicates other Gothic features in addition to the abject, (3) CUE-A communicates other Gothic features not including the abject, or (4) CUE-A communicates some other, as yet unidentified, concepts. While the evidence provided here strongly supports the idea that CUE-A is used as a visual metaphor for the abject in Gothic narratives, future research is required to converge upon a single conclusion. 


\subsection{SUMMARY}

In summary, CUE-A is a visual metaphor that consists of the combination of depicting a character as being physically close to the viewer (i.e., “Close-Up”), while simultaneously depicting asymmetry focused on or around the character's eyes (i.e., "Eye Asymmetry"). CUE-A implies the character is simultaneously like the viewer (i.e., kinship) and also unlike the viewer (i.e., other), thus indicating that the character exists in these two categories at the same time. As such, CUE-A can communicate the Gothic concept of the abject. This was tested by seeing if CUE-A is used more extensively when depicting a Gothic abject character (Batman) compared to a non-Gothic, non-abject character (Superman). In this study, I provided evidence for the following premises:

Premise 1: Batman is more Gothic than Superman

Premise 2: Batman is more abject than Superman

Premise 3: Batman is depicted with CUE-A more often than Superman.

Taken together, this indicates that CUE-A co-occurs with the concept of the abject in Gothic narratives, supporting the idea that the CUE-A visual metaphor does, in fact, communicate the abject in Gothic narratives.

\section{WORKS CITED}

“344 Clinton Street.” DC Database, FANDOM Comics Community, 19 April 2020, https://dc.fandom.com/wiki/344 Clinton Street\#cite ref-1.

Andrae, Thomas. "The Darkest Knight: The Gothic Roots of Batman Comics." Notes in the History of Art, vol. 40, no. 1, 2020, pp. 19-33. DOI:10.1086/711341.

Andrae, Thomas. "Of Supermen and Kids with Dreams". Nemo: The Classic Comics Library (2). Fantagraphics, pp. 6-19.

Bakhtin, Mikhail. Rabelais and His World. Translated by Helene Iswolsky, Indiana University Press, 1984.

Bruhm, Steven. "The Contemporary Gothic: Why We Need It." The Cambridge Companion to Gothic Fiction, edited by Jerrold E. Hogle, Cambridge University Press, 2002, pp. 259-276. DOI:10.1017/CCOL0521791243.013.

Bukatman, Scott. Matters of Gravity: Special Effects and Supermen in the 20th Century. Duke University Press, 2003.

Carello, Claudia, et al. “Static Depiction of Movement." Perception, vol. 15, no. 1, 1986, pp. 41-58. DOI:10.1068/p150041. 
Carroll, Noël. The Philosophy of Horror: Or, Paradoxes of the Heart. Routledge, 2003.

Cates, Isaac. "On the Literary Use of Superheroes; or, Batman and Superman Fistfight in Heaven." American Literature: A Journal of Literary History, Criticism, and Bibliography, vol. 83, no. 4, Dec. 2011, pp. 831-857. DOI:10.1215/00029831-1437234.

Cavallaro, Dani. Gothic Vision: Three Centuries of Horror, Terror \& Fear. Bloomsbury, 2002.

Conroy, Colette. "The Abject." The Handbook of the Gothic. 2nd ed., edited by Marie Mulvey-Roberts, New York University Press, 2009, p. 106.

Cremers, Martin. "Gotham City." Real Virtuality: About the Destruction and Multiplication of World, edited by Ulrich Gehmann and Martin Reiche, Transcript-Verlag, 2014, pp. 141-158.

"Definition of superhero in English." Lexico.com, 2021, https://www.lexico.com/en/definition/superhero.

Finger, Bill (w), and Bob Kane (a). Batman: The Legend of the Batman - Who He is, and How He Came to Be. Vol. 1, no. 1, DC Comics, Mar. 1940.

Finnerty, John R. "Did Internal Transport, Rather than Directed Locomotion, Favor the Evolution of Bilateral Symmetry in Animals?" BioEssays : News and Reviews in Molecular, Cellular and Developmental Biology, vol. 27, no. 11, Nov. 2005, pp. 1174-1180. DOI:10.1002/bies.20299.

Fisher, Mark. "Gothic Oedipus: Subjectivity and Capitalism in Christopher Nolan's Batman Begins" ImageTexT, vol. 2, no. 2, 2006. http://imagetext.english.ufl.edu/archives/v2_2/fisher/.

Fitch, Alex. "Gotham City and the Gothic Literary and Architectural Traditions." Studies in Comics, vol. 8, no. 2, Dec. 2017, pp. 205-225. DOI:10.1386/stic.8.2.205_1.

Forceville, Charles. "Conceptual Metaphor Theory, Blending Theory and Other Cognitivist Perspectives on Comics." The Visual Narrative Reader, edited by Neil Cohn, Bloomsbury Academic, 2016, pp. 89-114.

Gordon, Ian. Superman: The Persistence of an American Icon. Rutgers University Press, 2017.

Grant, Alan writer, and Norm Breyfogle (a). Batman: The Destroyer Part One: A Tale of Two Cities. Vol. 1, no. 474, DC Comics, Feb. 1992.

Hurley, Kelly. "Abject and Grotesque." The Routledge Companion to Gothic, edited by Catherine Spooner and Emma McEvoy, Routledge, 2007, pp. 137-146.

Johns, Geoff (w), and Gary Frank (a). Action Comics: Brainiac, Part 5: Finale. Vol. 1, no. 870, DC Comics, Dec. 2008.

Jensen, Randall M. "Batman's Promise." In Batman and Philosophy: The Dark Knight of the Soul, edited by Mark D. White and Robert Arp, John Wiley \& Sons, 2009, pp. 85-100.

Juricevic Igor. “Aladdin Sane and Close-Up Eye Asymmetry: David Bowie's Contribution to Comic Book Visual Language", The Comics Grid: Journal of Comics Scholarship vol. 7, no. 0, Mar. 2017, p. 4. DOI: $10.16995 / \mathrm{cg} .94$

Knox, Kelly. "Take a Tour of Batman's Hometown with 'Exploring Gotham City.'”DC Comic.com, 29 March 2021, https://www.dccomics.com/blog/2021/03/29/take-a-tour-of-batmans-hometownwith-exploring-gotham-city. 
Kress, Gunther, and Theo van Leeuwen. Reading Images: The Grammar of Visual Design. 2nd edition. Routledge, 2006.

Kristeva, Julia. Powers of Horror: An Essay on Abjection. Translated by Leon S. Roudiez. Columbia University Press, 1982.

Lakoff, George and Mark Johnson. Metaphors We Live By. The University of Chicago Press, 1980.

McCrystal, Erica. "Chaos, Order, and Liminality: The Urban Gothic of Fin-de-Siècle London and Gotham City." Gothic Studies, vol. 20, no. 1-2, Nov. 2018, pp. 311-325. DOI:10.7227/GS.0051.

Michaud, Nicolas. Batman, Superman, and Philosophy: Badass or Boyscout? Open Court, 2016.

Miller, Frank (w) and artist. Batman: The Dark Knight Returns, 30th Anniversary Edition. Collected Edition, DC Comics, Feb. 2016.

Monnet, Agnieszka Soltysik. "'I'll Be Whatever Gotham Needs Me to Be': Batman, the Gothic and Popular Culture." The Gothic in Contemporary Literature and Popular Culture: Pop Goth, edited by Justin D. Edwards and Agnieszka Soltysik Monnet, Routledge, 2012, pp. 96-113.

Nocenti, Ann (w), and Rafa Sandoval (a). The Joker: Death of the Family. Collected Edition, DC Comics, Oct. 2013.

Reinhart, Mark S. The Batman Filmography. 2nd edition. McFarland \& Company, 2013.

Round, Julia. Gothic in Comics and Graphic Novels: A Critical Approach. McFarland \& Company, 2014.

Sanna, Antonio. "Batman: Gothic Conventions and Terror." Aeternum: The Journal of Contemporary Gothic Studies, vol. 2, no. 2, Dec. 2015, pp. 33-45.

Skott, Sara, et al. "In the Shadow of the Monster: Gothic Narratives of Violence Prevention." Critical Criminology, vol. 29, no. 2, June 2021, pp. 385-400. DOI:10.1007/s10612-020-09529-x.

Sothcott, Keir. "Late Modern Ambiguity and Gothic Narratives of Justice." Critical Criminology, vol. 24, no. 3, Sept. 2016, pp. 431-444. DOI:10.1007/s10612-015-9287-2.

Stern, Roger (w), and Jackson Guice (a). Superman: The Return of Superman. Collected Editon, DC Comics, Apr. 2016.

"Stronger Together." Supergirl, written by Greg Berlanti, directed by Glen Winter, Warner Brothers, 2015.

Waid, Mark (w), and Bryan Hitch (a). JLA: Dream Team. Vol. 1, no. 50, DC Comics, Feb. 2001.

Waid, Mark (w), and Leinil Francis Yu (a). Superman: Birthright: Heart of Darkness. Vol. 1, no. 2, DC Comics, Oct. 2003.

Wandtke., Terrence R. The Meaning of Superhero Comic Books. McFarland \& Company, 2012.

\section{IMAGE SOURCES}

Azzarello, Brian (w), and Lee Bermejo (a). Absolute Joker/Luthor: Front Cover. Collected Edition, DC Comics, Oct. 2013. (Fig. 7)

- (w), and Lee Bermejo (a). Absolute Joker/Luthor: Back Cover. Collected Edition, DC Comics, Oct. 2013. (Fig. 7) 
Bedard, Tony (w), and Gene Ha (a). Superman: Recollection. Vol. 3, no. 23.2, DC Comics, Nov. 2013. (Fig. 7)

Bianchi, Simone (a). Batman: Secrets of the Batcave. Collected Edition, DC Comics, Aug. 2007. (Fig. 6)

Busiek, Kurt (w), and Renato Guedes (a). Superman: Shadows Linger (Part I) - Brighter Tomorrows. Vol. 1, no. 674, DC Comics, May 2008. (Fig. 5)

Connor, Amanda (w) and artist. Harley Quinn: Kingpin Queen. Vol. 2, no. 23, DC Comics, Feb. 2016. (Fig. 2)

Dell'otto, Gabriele (a). Action Comics. Vol. 1, no. 1000, DC Comics, June 2018. (Fig. 6)

Dixon, Chuck (w), and Jim Aparo (a). Detective Comics: Death Comes Home. Vol. 1, no. 716, DC Comics, Dec. 1997. (Fig. 1)

Finger, Bill (w), and Wayne Boring (a). Superman: Superman's Neighbors. Vol. 1, no. 112, DC Comics, Mar. 1957. (Fig. 5)

Harris, Joe (w), and Juan Doe (a). Joker's Asylum: Dark Knight of the Scarecrow. Vol. 1, no. 1, DC Comics, Sep. 2008. (Fig. 2)

Helfer, Andrew (w), and Neal Adams (a). Batman Annual: The Eye of the Beholder. Vol. 1, no. 14, DC Comics, July 1990. (Fig. 2)

Hurwitz, Gregg (w), and Szymon Kudranski (a). Penguin: Pain and Prejudice: Beautiful Boy. Vol. 1, no. 2, DC Comics, Jan. 2012. (Fig. 2)

Jenkins, Paul (w), and David Finch (a). Batman: The Dark Knight: Run Rabbit Run. Vol. 2, no. 6, DC Comics, Apr. 2012. (Fig. 7)

Jurgens, Dan (w), and Patrick Zircher (a). Action Comivcs: Revenge, Part 3. Vol. 1, no. 981, DC Comics, Aug. 2017. (Fig. 7)

King, Tom (w), and David Finch (a). Batman: I Am Bane, Part Five. Vol. 3, no. 20, DC Comics, June 2017. (Fig. 2)

- (w), and Jim Lee (a). Batman/Catwoman: The Bat \& The Cat, Chapter 5: Jingle Bells. Vol. 1, no. 5, DC Comics, Aug. 2021. (Fig. 2)

Lee, Jim (a). Action Comics. Vol. 1, no. 1000, DC Comics, June 2018. (Fig. 4)

Loeb, Jeph (w), and Jim Lee (a). Batman: Hush, Part Twelve: The End. Vol. 1, no. 619, DC Comics, Nov. 2003. (Fig. 2)

- (w), and Tim Sale (a). Batman: The Long Halloween. Collected Edition, DC Comics, Oct. 1998. (Fig. 5)

- (w), and Tim Sale (a). Batman: Haunted Knight. Collected Edition, DC Comics, Sep. 1996. (Fig. 5)

Luen Yang, Gene (w), and Greg Capullo (a). Batman/Superman: Phantoms. Vol. 1, no. 19, DC Comics, Apr. 2015. (Fig. 3)

March, Guillem (a). Batman Arkham: Clayface. Collected Edition, DC Comics, Aug. 2017. (Fig. 7)

Moench, Doug (w), and Mike Manley (a). Batman: Prodigal: Part I - Robin and Batman. Vol. 1, no. 512, DC Comics, Nov. 1994. (Fig. 7)

Moore, Alan (w), and Brian Bolland (a). Batman: The Killing Joke. Vol. 1, no. 1, DC Comics, July 1988. (Fig. 2) 
Morrison, Grant (w), and David Finch (a). Batman: Time and the Batman. Vol. 1, no. 700, DC Comics, Aug. 2010. (Fig. 4)

Pak, Greg (w), and Jae Lee (a). Batman/Superman: Cross World. Vol. 1, no. 1, DC Comics, Aug. 2013. (Fig. 3)

Snyder, Scott (w), and Jason Fabok (a). Batman Annual: Night of the Owls: First Snow. Vol. 2, no. 1, DC Comics, July 2012. (Fig. 2)

Stern, Roger (w), and Art Thibert, cover artist. Action Comics: Man of the Hour. Vol. 1, no. 676, DC Comics, Apr. 1992. (Fig. 1)

Tieri, Frank (w), and Jason Fabok (a). Batman: The Penguin: Bullies. Vol. 2, no. 23.3, DC Comics, Nov. 2013. (Fig. 7)

Tomasi, Peter (w), and Brian Bolland (a). Batman and Robin: The Big Burn: Sparks. Vol. 2, no. 25, DC Comics, Jan. 2014. (Fig. 7) 